

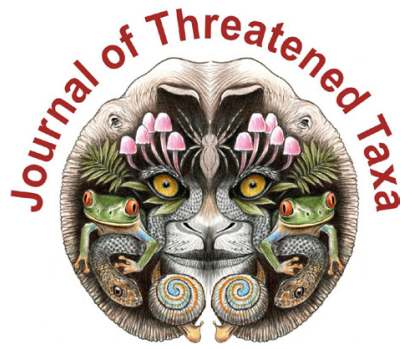

ISSN 0974-7907 (Online); ISSN $0974-7893$ (Print)

Publisher

Host

Wildlife Information Liaison Development Society

www.wild.zooreach.org

Zoo Outreach Organization www.zooreach.org

No. 12, Thiruvannamalai Nagar, Saravanampatti - Kalapatti Road, Saravanampatti, Coimbatore, Tamil Nadu 641035, India

Ph: +91 9385339863 | www.threatenedtaxa.org

Email: sanjay@threatenedtaxa.org

EDITORS

\section{Founder \& Chief Editor}

Dr. Sanjay Molur

Wildlife Information Liaison Development (WILD) Society \& Zoo Outreach Organization (ZOO),

12 Thiruvannamalai Nagar, Saravanampatti, Coimbatore, Tamil Nadu 641035, India

\section{Deputy Chief Editor}

Dr. Neelesh Dahanukar

Noida, Uttar Pradesh, India

\section{Managing Editor}

Mr. B. Ravichandran, WILD/ZOO, Coimbatore, India

\section{Associate Editors}

Dr. Mandar Paingankar, Government Science College Gadchiroli, Maharashtra 442605, India

Dr. Ulrike Streicher, Wildlife Veterinarian, Eugene, Oregon, USA

Ms. Priyanka Iyer, ZOO/WILD, Coimbatore, Tamil Nadu 641035, India

Dr. B.A. Daniel, ZOO/WILD, Coimbatore, Tamil Nadu 641035, India

\section{Editorial Board}

Dr. Russel Mittermeier

Executive Vice Chair, Conservation International, Arlington, Virginia 22202, USA

\section{Prof. Mewa Singh Ph.D., FASc, FNA, FNASc, FNAPsy}

Ramanna Fellow and Life-Long Distinguished Professor, Biopsychology Laboratory, and Institute of Excellence, University of Mysore, Mysuru, Karnataka 570006, India; Honorary Professor, Jawaharlal Nehru Centre for Advanced Scientific Research, Bangalore; and Adjunct Professor, National Institute of Advanced Studies, Bangalore

\section{Stephen D. Nash}

Scientific Illustrator, Conservation International, Dept. of Anatomical Sciences, Health Sciences Center, T-8, Room 045, Stony Brook University, Stony Brook, NY 11794-8081, USA

\section{Dr. Fred Pluthero}

Toronto, Canada

\section{Dr. Priya Davidar}

Sigur Nature Trust, Chadapatti, Mavinhalla PO, Nilgiris, Tamil Nadu 643223, India

\section{Dr. Martin Fisher}

Senior Associate Professor, Battcock Centre for Experimental Astrophysics, Cavendish

Laboratory, JJ Thomson Avenue, Cambridge CB3 OHE, UK

\section{Dr. John Fellowes}

Honorary Assistant Professor, The Kadoorie Institute, 8/F, T.T. Tsui Building, The University of Hong Kong, Pokfulam Road, Hong Kong

\section{Prof. Dr. Mirco Solé}

Universidade Estadual de Santa Cruz, Departamento de Ciências Biológicas, Vice-coordenado do Programa de Pós-Graduação em Zoologia, Rodovia Ilhéus/Itabuna, Km 16 (45662-000)

Salobrinho, Ilhéus - Bahia - Brasil

\section{Dr. Rajeev Raghavan}

Professor of Taxonomy, Kerala University of Fisheries \& Ocean Studies, Kochi, Kerala, India

\section{English Editors}

Mrs. Mira Bhojwani, Pune, India

Dr. Fred Pluthero, Toronto, Canad

Mr. P. Ilangovan, Chennai, India

Web Development

Mrs. Latha G. Ravikumar, ZOO/WILD, Coimbatore, India

\section{Typesetting}

Mr. Arul Jagadish, ZOO, Coimbatore, India

Mrs. Radhika, ZOO, Coimbatore, India

Mrs. Geetha, ZOO, Coimbatore India
Fundraising/Communications

Mrs. Payal B. Molur, Coimbatore, India

Subject Editors 2018-2020

Fungi

Dr. B. Shivaraju, Bengaluru, Karnataka, India

Dr. R.K. Verma, Tropical Forest Research Institute, Jabalpur, India

Dr. Vatsavaya S. Raju, Kakatiay University, Warangal, Andhra Pradesh, India

Dr. M. Krishnappa, Jnana Sahyadri, Kuvempu University, Shimoga, Karnataka, India

Dr. K.R. Sridhar, Mangalore University, Mangalagangotri, Mangalore, Karnataka, India

Dr. Gunjan Biswas, Vidyasagar University, Midnapore, West Bengal, India

\section{Plants}

Dr. G.P. Sinha, Botanical Survey of India, Allahabad, India

Dr. N.P. Balakrishnan, Ret. Joint Director, BSI, Coimbatore, India

Dr. Shonil Bhagwat, Open University and University of Oxford, UK

Prof. D.J. Bhat, Retd. Professor, Goa University, Goa, India

Dr. Ferdinando Boero, Università del Salento, Lecce, Italy

Dr. Dale R. Calder, Royal Ontaro Museum, Toronto, Ontario, Canada

Dr. Cleofas Cervancia, Univ. of Philippines Los Baños College Laguna, Philippines

Dr. F.B. Vincent Florens, University of Mauritius, Mauritius

Dr. Merlin Franco, Curtin University, Malaysia

Dr. V. Irudayaraj, St. Xavier's College, Palayamkottai, Tamil Nadu, India

Dr. B.S. Kholia, Botanical Survey of India, Gangtok, Sikkim, India

Dr. Pankaj Kumar, Kadoorie Farm and Botanic Garden Corporation, Hong Kong S.A.R., China

Dr. V. Sampath Kumar, Botanical Survey of India, Howrah, West Bengal, India

Dr. A.J. Solomon Raju, Andhra University, Visakhapatnam, India

Dr. Vijayasankar Raman, University of Mississippi, USA

Dr. B. Ravi Prasad Rao, Sri Krishnadevaraya University, Anantpur, India

Dr. K. Ravikumar, FRLHT, Bengaluru, Karnataka, India

Dr. Aparna Watve, Pune, Maharashtra, India

Dr. Qiang Liu, Xishuangbanna Tropical Botanical Garden, Yunnan, China

Dr. Noor Azhar Mohamed Shazili, Universiti Malaysia Terengganu, Kuala Terengganu, Malaysia

Dr. M.K. Vasudeva Rao, Shiv Ranjani Housing Society, Pune, Maharashtra, India

Prof. A.J. Solomon Raju, Andhra University, Visakhapatnam, India

Dr. Mandar Datar, Agharkar Research Institute, Pune, Maharashtra, India

Dr. M.K. Janarthanam, Goa University, Goa, India

Dr. K. Karthigeyan, Botanical Survey of India, India

Dr. Errol Vela, University of Montpellier, Montpellier, France

Dr. P. Lakshminarasimhan, Botanical Survey of India, Howrah, India

Dr. Larry R. Noblick, Montgomery Botanical Center, Miami, USA

Dr. K. Haridasan, Pallavur, Palakkad District, Kerala, India

Dr. Analinda Manila-Fajard, University of the Philippines Los Banos, Laguna, Philippines

Dr. P.A. Sinu, Central University of Kerala, Kasaragod, Kerala, India

Dr. Afroz Alam, Banasthali Vidyapith (accredited A grade by NAAC), Rajasthan, India

Dr. K.P. Rajesh, Zamorin's Guruvayurappan College, GA College PO, Kozhikode, Kerala, India

Dr. David E. Boufford, Harvard University Herbaria, Cambridge, MA 02138-2020, USA

Dr. Ritesh Kumar Choudhary, Agharkar Research Institute, Pune, Maharashtra, India

Dr. Navendu Page, Wildlife Institute of India, Chandrabani, Dehradun, Uttarakhand, India

\section{Invertebrates}

Dr. R.K. Avasthi, Rohtak University, Haryana, India

Dr. D.B. Bastawade, Maharashtra, India

Dr. Partha Pratim Bhattacharjee, Tripura University, Suryamaninagar, India

Dr. Kailash Chandra, Zoological Survey of India, Jabalpur, Madhya Pradesh, India

Dr. Ansie Dippenaar-Schoeman, University of Pretoria, Queenswood, South Africa

Dr. Rory Dow, National Museum of natural History Naturalis, The Netherlands

Dr. Brian Fisher, California Academy of Sciences, USA

Dr. Richard Gallon, llandudno, North Wales, LL30 1UP

Dr. Hemant V. Ghate, Modern College, Pune, India

Dr. M. Monwar Hossain, Jahangirnagar University, Dhaka, Bangladesh

Mr. Jatishwor Singh Irungbam, Biology Centre CAS, Branišovská, Czech Republic.

Dr. Ian J. Kitching, Natural History Museum, Cromwell Road, UK

Dr. George Mathew, Kerala Forest Research Institute, Peechi, India

For Focus, Scope, Aims, and Policies, visit https://threatenedtaxa.org/index.php/JoTT/aims_scope
For Article Submission Guidelines, visit https://threatenedtaxa.org/index.php/JoTT/about/submissions
For Policies against Scientific Misconduct, visit https://threatenedtaxa.org/index.php/JoTT/policies_various

continued on the back inside cover 


\title{
Roadkills of Lowland Tapir Tapirus terrestris (Mammalia: Perissodactyla: Tapiridae) in one of its last refuges in the Atlantic Forest
}

\author{
Aureo Banhos ${ }^{1}$ (D), Andressa Gatti ${ }^{2}$ D, Marcelo Renan de Deus Santos ${ }^{3}$ (D), Leonardo Merçon ${ }^{4}$ (D), \\ Ilka Westermeyer ${ }^{5}$ (D), Natália Carneiro Ardente ${ }^{6}$ iD, Luis Francisco Oliveira Pereira Gonzaga ${ }^{7}$, \\ Lucas Mendes Barreto ${ }^{8} \mathbb{D}$, Lucas Damásio ${ }^{9} \mathbb{D}$, Tomas Lima Rocha ${ }^{10} \mathbb{D}$, Vitor Roberto Schettino ${ }^{11}(\mathbb{D}$, \\ Renata Valls ${ }^{12}$ iD, Helena Godoy Bergallo ${ }^{13}$ iD, Marcos Vinicius Freitas Silva ${ }^{14}$, \\ Athelson Stefanon Bittencourt ${ }^{15}$ D , Danielle de Oliveira Moreira ${ }^{16}$ (D) \& Ana Carolina Srbek-Araujo ${ }^{17}$ (D)

\begin{abstract}
${ }_{1,8,9,11}$ Departamento de Biologia, Centro de Ciências Exatas, Naturais e da Saúde, Universidade Federal do Espírito Santo, Alto Universitário, s/no, Guararema, 29500-000, Alegre, ES, Brazil.

${ }^{1,7,10}$ Programa de Pós-graduação em Ciências Biológicas (Biologia Animal), Centro de Ciência Humana e Naturais, Universidade Federal do Espírito Santo, Avenida Fernando Ferrari, 514, Goiabeiras, 29075-910, Vitória, ES, Brazil.

${ }^{2}$ Instituto Pró-Tapir para a Biodiversidade, Rua Luiz Fernandes Reis, n² 230, 29101-120, Praia da Costa, Vila Velha, ES, Brazil.

${ }^{2,16}$ Instituto Nacional da Mata Atlântica, Avenida José Ruschi, n 4, 29650-000, Santa Teresa, ES, Brazil.

${ }^{3}$ Laboratório de Ictiologia Aplicada, Universidade Vila Velha, Avenida Comissário José Dantas de Mello, n²1, 29102-920, Vila Velha, ES, Brazil. ${ }^{3}$ Instituto Marcos Daniel, Rua Fortunato Ramos, n 123, 29056-020, Santa Lucia, Vitória, ES, Brazil.

4,5 Instituto Últimos Refúgios, Rua Humberto Balbi, n²1, Edifício Renê Descartes, sala 208, Jardim Camburi, 29092-080, Vitória, ES, Brazil.

6,12,13 Programa de Pós-graduação em Ecologia e Evolução, Laboratório de Ecologia de Mamíferos, Universidade do Estado do Rio de Janeiro, Rua São Francisco Xavier, n 524, Maracanã, 20550-900, Rio de Janeiro, RJ, Brazil.

${ }^{13}$ Departamento de Ecologia, Instituto de Biologia Roberto Alcântara Gomes, Universidade do Estado do Rio de Janeiro, Rua São Francisco Xavier, n 524, Maracanã, 20550-900, Rio de Janeiro, RJ, Brazil.

${ }_{14,15}$ Museu de Ciências da Vida, Universidade Federal do Espírito Santo, Avenida Fernando Ferrari, 514, Goiabeiras, 29075-910, Vitória, ES, Brazil. 17 Programa de Pós-graduação em Ecologia de Ecossistemas e Programa de Pós-graduação em Ciência Animal, Laboratório de Ecologia e Conservação de Biodiversidade, Universidade Vila Velha, Rua Comissário José Dantas de Melo, n²1, Boa Vista, 29102-920, Vila Velha, ES, Brazil.

${ }^{17}$ Instituto SerraDiCal de Pesquisa e Conservação, Rua José Hemetério Andrade, 570, bloco 06, apto 201, Buritis, 30493-180, Belo Horizonte, MG, Brazil.

13aureo.santos@ufes.br (corresponding author), 2'gatti.andressa@gmail.com, ${ }^{3}$ mrenansantos@gmail.com, ${ }^{4}$ leonardomercon@gmail.com,

5ilka.westermeyer@gmail.com, ${ }^{5}$ natalia_ardente@hotmail.com, 7luispof@gmail.com, 8 lucasbarreto.bio@gmail.com,

${ }^{9}$ damasioler@gmail.com, ${ }^{10} 92 . t o m a s @ g m a i l . c o m, ~{ }^{11}$ schettino.vitor@gmail.com, ${ }^{12}$ renata.pagotto@gmail.com,

${ }^{13}$ nena.bergallo@gmail.com, ${ }^{14}$ Marcos.vinicius.freitas.silva@gmail.com, ${ }^{15}$ athelson.bittencourt@ufes.br, ${ }^{16}$ daniomoreira@gmail.com, ${ }^{17}$ srbekaraujo@hotmail.com
\end{abstract}

\begin{abstract}
Highways limit the movement and dispersion of wild animals and contribute to their loss due to roadkills, leading to the isolation and decline of populations, increasing the risk of local extinction. The Lowland Tapir Tapirus terrestris is the largest neotropical herbivorefrugivore, and despite its wide distribution in South America it is threatened with extinction. In this study we report six roadkill events of tapirs between 2014 and 2019 in a section of a federal highway crossing the mosaic of Atlantic Forest reserves called Sooretama, one of the last tapir refuges in southeastern Brazil. The traffic in this area is heavy with inadequate speed control, while exotic fruit trees growing along the highway attract wild animals. Water drainage tunnels serve as passageways for some species, including tapirs. However, the tunnels located under the highway are not continuously maintained, reducing its effectiveness. The loss of at least one tapir per year can have serious long-term consequences for one of the last viable lowland tapir populations in the entire Atlantic Forest. Emergency measures are required to avoid vehicle-tapir collisions.
\end{abstract}

Keywords: Brazil, mitigation measures, road ecology, Sooretama, threatened species.

Citation: Banhos, A., A. Gatti, M.R.de D. Santos, L. Merçon, I. Westermeyer, N.C. Ardente, L.F.O.P. Gonzaga, L.M. Barreto, L. Damásio, T.L. Rocha, V.R. Schettino, R. Valls, H.G. Bergallo, M.V.F. Silva, A.S. Bittencourt, D.de O. Moreira \& A.C. Srbek-Araujo (2021). Roadkills of Lowland Tapir Tapirus terrestris (Mammalia: Perissodactyla: Tapiridae) in one of its last refuges in the Atlantic Forest. Journal of Threatened Taxa 13(13): 19921-19929. https://doi.org/10.11609/jott.6901.13.13.19921-19929

Copyright: ( $)$ Banhos et al. 2021. Creative Commons Attribution 4.0 International License. JoTT allows unrestricted use, reproduction, and distribution of this article in any medium by providing adequate credit to the author(s) and the source of publication.

Funding: This study was funded by the UFES, the Fundação de Amparo à Pesquisa do Espírito Santo (FAPES) [grant numbers 61901857/2013, 0607/2015, 510/2016, and 527/2016], the Fundação de Amparo à Pesquisa do Estado do Rio de Janeiro (FAPERJ) [grant number E26/201.267/2014], the Prociência of UERJ and National Council of Technological and Scientific Development (CNPq) [grant number 307781/2014-3 and 457458/2012-7)].

Competing interests: The authors declare no competing interests.

Author details, Author contributions, Acknowledgements \& Português abstract: See end of this article. 


\section{INTRODUCTION}

Roads and highways lead to habitat loss and fragmentation, create barriers that limit the movement and dispersion of organisms, limit genetic flows, prevent wildlife from accessing resources that are vital for their survival, and cause direct animal mortality due to roadkill incidents, all with negative effects on biodiversity (Forman \& Alexander, 1998; Trombulak \& Frissell 2000; Coffin 2007; Laurance et al. 2009; Holderegger \& Di Giulio 2010). Large mammal populations are among the most negatively affected by the presence of roads, mainly because they travel long distances, cross different roads, and have low reproductive rates and population densities (Fahrig \& Rytwinski 2009).

In Brazil, one of the large mammal species affected by highways is the Lowland Tapir Tapirus terrestris (Linnaeus, 1758) (Grilo et al. 2018), the largest terrestrial mammal of Neotropics, with a body length of 1.70 to $2.00 \mathrm{~m}$ and weight up to $300 \mathrm{~kg}$ (Padilla \& Dowler 1994; Eisenberg \& Redford 1999; Medici 2011). This species presents the largest distribution within the genus and is found in the lowland regions of northern and central South America (Padilla \& Dowler 1994; Eisenberg \& Redford 1999; Varela et al. 2019). Despite its wide geographic distribution, the species is currently classified as Vulnerable, both globally (Varela et al. 2019) and in the Brazilian territory (Medici 2018). Nevertheless, in the Atlantic Forest, one of the most threatened biodiversity hotspots in the world (Myers et al. 2000), the conservation status of the Lowland Tapir is even more worrying because its habitat has been reduced to a few fragments and its population is extremely small, being reduced to a small number of areas (Medici et al. 2018).

The main conservation threats to the Lowland Tapir are habitat loss, poaching and competition with livestock (García et al. 2012; Medici et al. 2012, 2018; Varela et al. 2019). However, in recent years, roadkill incidents with tapirs have attracted increasing attention due to their negative consequences. In Brazil, tapirs killed by collisions with vehicles have been reported in the Amazon (Carvalho et al. 2014; de Freitas et al. 2017), Pantanal (de Souza et al. 2015), Cerrado (Ascensão et al. 2017), transitional areas between Cerrado and the Atlantic Forest (Cáceres et al. 2010; Cáceres 2011), and the southwestern region of the Atlantic Forest (Medici \& Desbiez 2012). These events are even more severe for tapir populations when combined with other threats, especially in the Atlantic Forest, where very few areas support viable populations of more than 200 individuals (Medici et al. 2012).
Here we report tapir roadkills and relate them to the species' high locomotion ability combined with poor road management in one of the last areas with viable Lowland Tapir populations, located in the north of Espírito Santo State, southeastern Brazil (Flesher \& Gatti 2010; Gatti et al. 2011; Medici et al. 2012; Ferreguetti et al. 2017), in a complex of protected areas known as Sooretama. Sooretama, which means "land of the animals of the forest" in the Brazilian native language Tupi Guarani (Instituto Brasileiro de Desenvolvimento Florestal 1981), consists of a group of four protected areas amount approximately 53,000 ha. These areas have been recognized as one of the best preserved large lowland forests with high priority for the conservation of large mammals in the biome (Galetti et al. 2009).

\section{METHODS}

\section{Study area}

We conducted the study in a forest complex formed by Sooretama Biological Reserve (SBR; 27,858 ha), a federal protected area; the Vale Natural Reserve (VNR; 22,711 ha), a private protected area; the Private Natural Heritage Reserves (PNHR) Recanto das Antas (2,212 ha) and the PNHR Mutum-Preto (379 ha) (Figure $1)$. This contiguous protected areas complex is one of the 77 Atlantic Forest remnants with more than 10,000 ha (Ribeiro et al. 2009), located between the coordinates $-18.905458,-40.212713$ and -19.244815 , -39.945269, in the northern part of the Espírito Santo state, southeastern Brazil, hereon referred as Sooretama (Figure 1).

The Sooretama reserves form one of the largest remnants of Tabuleiro Atlantic Forest, a lowland forest (formed on sedimentary plains originated in the Pliocene) intersected by wide and shallow valleys (Rolim et al. 2016). The climate is tropical with dry winter (Aw) according to Köppen's system (Alvares et al. 2013). Since the 1960's, the Sooretama forest complex has been bisected by the busiest highway in Brazil, the federal BR101 highway (Instituto Brasileiro de Desenvolvimento Florestal 1981) (Figure 1). Approximately 23 kilometers of BR-101 intersects the SBR buffer zone, with 5 kilometers crossing the interior of SBR (Figure 1).

\section{Data collection}

We obtained data on tapirs killed by collisions with vehicles on the section of BR-101 crossing Sooretama between 2014 and 2019. The roadkill events were reported to us by the SBR staff. We visited the sites, 




Figure 1. Records of six roadkill events of lowland tapirs in a section of BR-101 highway, crossing the Sooretama complex, in southeastern Brazil.

recorded the date, the location on the highway, and the age class and sex of each animal. Necropsies were performed on individuals that were not in an advanced stage of decomposition. The tapir bones and heads were collected and deposited at the Museu de Ciências da Vida (Museum of Life Sciences), Federal University of Espírito Santo.

\section{RESULTS}

We recorded six events of tapir roadkills in the study area: two males (an adult and another juvenile) and four females (three adults and juvenile) (Figure 1; Table1; Image 1). The second roadkilled tapir was a pregnant adult female with a well-developed male fetus (Últimos Refúgios 2014a; Image 2). Two other tapirs were found on the roadside in an advanced stage of decomposition, one on 17 September 2015, and another on 15 September 2019 (Table 1). The roadkill of the last tapir was reported by a highway user who saw the moment of the collision in the late afternoon, days before the
Table 1. Records of roadkill events of lowland tapirs in a section of BR101 highway that crossing the Sooretama complex, in southeastern Brazil.

\begin{tabular}{|c|l|l|l|l|l|}
\hline Date & Sex & $\begin{array}{l}\text { Life } \\
\text { stage }\end{array}$ & Km & Period & Vehicle type \\
\hline 30.vi.2014 & male & adult & 119 & night & truck \\
\hline 24.x.2014 & female & adult & 121 & night & car \\
\hline 08.ii.2015 & male & juvenile & 116 & night & car \\
\hline 17.ix.2015 & female & adult & 120 & unidentified & unidentifield \\
\hline 17.ii.2018 & female & adult & 119 & night & bus \\
\hline 15.ix.2019 & female & juvenile & 105 & afternoon & truck \\
\hline
\end{tabular}

animal being found dead. Four confirmed roadkills occurred at night and one afternoon, caused by two cars, two trucks, and one bus (Table 1). Five tapirs were roadkill on the stretch of the highway that cuts through the VNR, in the SBR buffer zone (Figure 1). Only the last roadkill happened within the SBR area (Figure 1 ). 


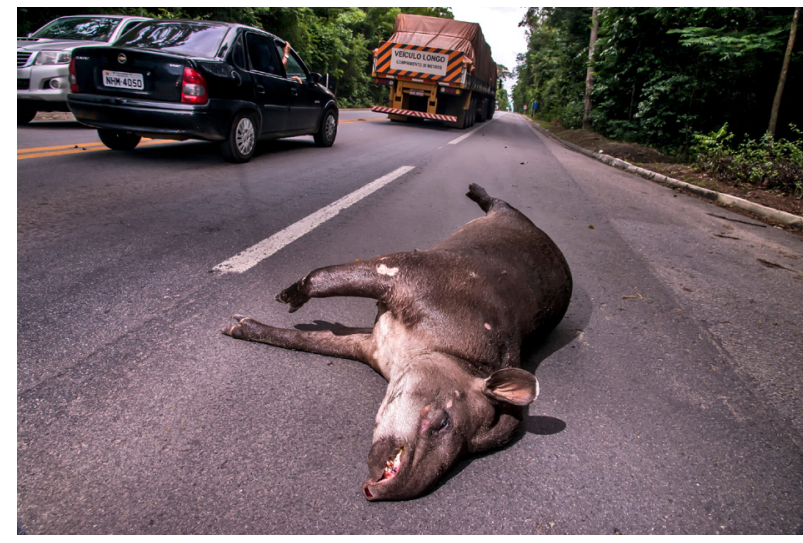

Image 1. Photo of juvenile male Lowland Tapir roadkilled at km 116 of the BR-101 highway in Sooretama, on 8 February 2015.

\section{DISCUSSION}

In the six decades since its construction, many animals of various species have been killed on this portion of the BR-101 (Instituto Brasileiro de Desenvolvimento Florestal 1981; Klippel et al. 2015; Srbek-Araujo et al. 2015; Damásio et al. 2021). Since 2014, we have followed roadkill records of tapirs to understand their negative effects on the conservation of the species in the forest complex of Sooretama. Roadkill records described in this study are extremely worrisome for the lowland tapir conservation on Espírito Santo, as well as on the Atlantic Forest biome as a whole. There is only one known record from before the monitoring period of a Lowland Tapir killed via a vehicle collision in the neighboring area of Sooretama. This occurred in 1997, when a school bus hit a tapir on an unpaved road located south of Sooretama reserves, in Córrego Farias, municipality of Linhares (Lorenzutti \& Almeida 2006). Unlike this isolated record, this study shows that the loss of Lowland Tapir due to vehicle collisions is an old problem in the region, emphasizing the role of this threat in removing individuals of reproductive age from the population of Sooretama.

It is possible that some tapir deaths due to collisions were not recorded. Animals may have died in the forest due to injuries resulting from a collision, or carcasses may have been lost for other reasons. For instance, two tapirs were found only days after they were roadkilled, when the presence of vultures and decaying animal smell near the highway was noticed. Nonetheless, on 21 July 2019 we received notification of another tapir roadkill on BR-101 but its carcass was not found. Thus it is likely that we underestimated the number of tapir roadkills.

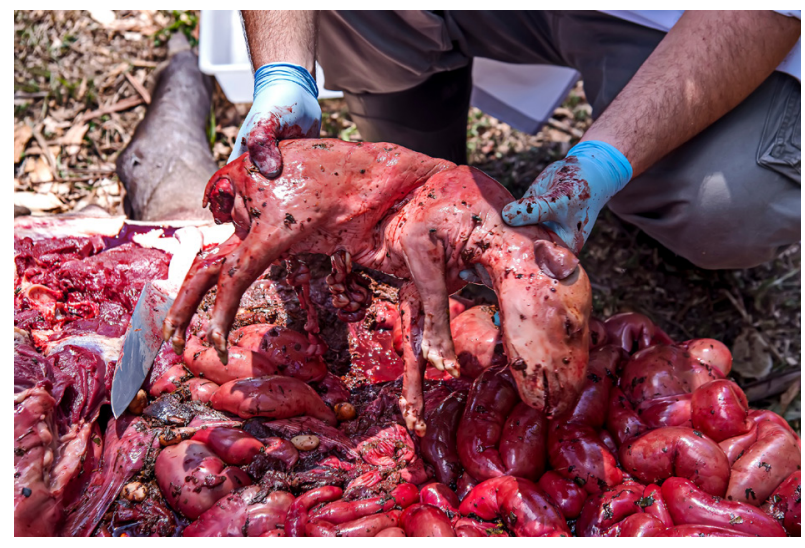

Image 2. Photo of a fetus of a pregnant Lowland Tapir roadkilled at km 121 of the BR-101 highway in Sooretama, on 24 October 2014.

Tapir roadkills occurred most often at night and outside of the SBR area, on a stretch of highway within VNR fragmented forest. These factors must be considered in designing mitigation strategies. In addition to tapirs, other large mammals have been killed within the SBR area, including a Jaguar Panthera onca in 2000 (SrbekAraujo et al. 2015) and two Pumas Puma concolor, one in 2009 (Srbek-Araujo et al. 2015) and another in 2015 (Últimos Refúgios 2015).

Roadkill events can rapidly reduce tapir population growth and increase the probability of local extinction, especially when adults and sub-adult females are lost (Medici \& Desbiez 2012). Tapirs are long-lived and have slow reproductive rates, which makes the species more vulnerable to anthropogenic pressures (Medici \& Desbiez 2012; Medici et al. 2012; Varela et al. 2019). In Sooretama, of the six recorded tapir kills, four were adult and sub-adult females. According to Ferreguetti et

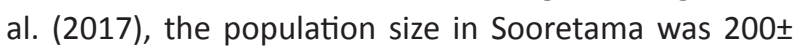
33 individuals, which suggests that the local population is genetically and demographically viable, based on the population viability analysis for the species in the Atlantic Forest (Gatti et al. 2011; Medici \& Desbiez 2012). However, the incidence of female roadkill can be a warning for the long-term survival of the population. Tapir population reduction and even extinction can result in the loss of ecological services, such as seed dispersal (Barcelos et al. 2013; Bueno et al. 2013; Giombini et al. 2016; Paolucci et al. 2019), since they are responsible for dispersing seeds of high wood density trees that store tons of carbon, thus providing an ecological service with an estimated worth of billions of dollars (Bello et al. 2015; Peres et al. 2015). 


\section{Wildlife underpasses and their use by tapirs on the BR- 101 highway}

The stretch of the BR-101 that intercepts Sooretama is a straight paved road with 23 water drainage culverts (hereafter "tunnels"), and some of them are used by wild species (Banhos et al. 2020). Five of these tunnels are tall and wide (more than $2 \mathrm{~m}$ in diameter) and are frequently used by mammals, such as lowland tapirs. Since 2014 , the use of these tunnels by wild animals has been monitored using camera traps, and tapirs were registered using the crossings (Video 1). Despite this, the six killed tapirs were found close to the big tunnels (between $5 \mathrm{~m}$ and $800 \mathrm{~m}$ away), at km 106, 116, 119, and 120 .

Although wild animals are using the tunnels in the area, the lack of maintenance and cleaning of the structures results in tunnels completely obstructed by sediments, branches, and tree trunks, often precluding the use by of wildlife. During the camera trap monitoring period, we did not witness any event of tunnel maintenance or cleaning. Occasionally, we cleaned the tunnels ourselves. On 22 September 2015, a camera recorded an attempt by a tapir to cross the tunnel at

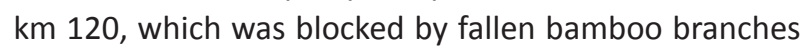
(Video 2). We confirmed in the images of the cameras that the blockade happened on 11 September 2015 and that a tapir went through the tunnel days before, on 8 September 2015. Five meters from the tunnel entrance, a tapir was found dead on 17 September 2015.

Tunnels are often used as wildlife passages and are therefore one of the measures used to mitigate roadkill incidents. Even though the tunnels in BR-101 were not originally installed as a mitigation measure, they are often used for crossings by some species. Thus, these tunnels make the highways less risky for wildlife (Clevenger et al. 2001; Goosem et al. 2001; Cain et al. 2003; Taylor \& Goldingay 2003; Dodd Jr. et al. 2004; Ascensão \& Mira 2007; McCollister \& Manen 2010; Lesbarrères \& Fahrig 2012). However, periodic maintenance of the tunnels is necessary so that they can be effectively used by fauna.

\section{Socioeconomic impacts and risks for highway users}

The high speed of vehicles is one of the factors that increases the risk of roadkill events (Forman \& Alexander 1998; Fahrig \& Rytwinski 2009), and the largesized vertebrates killed along the BR-101 highway in Sooretama in recent years are indicatives of that. It was not uncommon to observe reckless drivers that ignored the speed cameras when they were operating.

From June 2014 and October 2016, we measured the speed of vehicles (including cars and trucks) driving

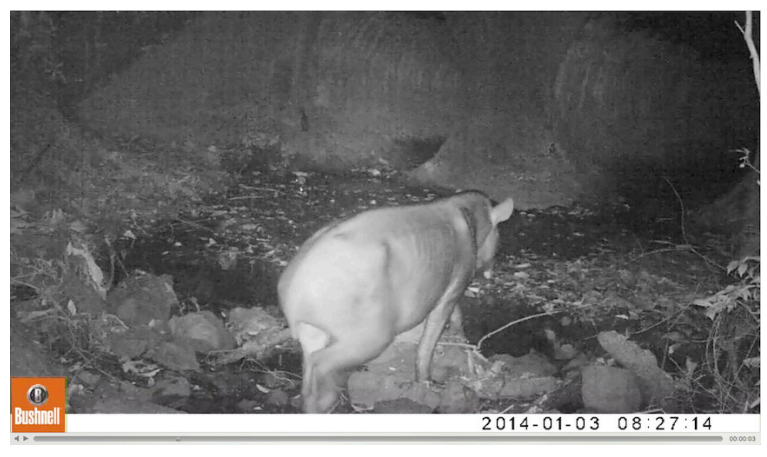

Video 1. Video of Lowland Tapir crossing the tunnel at km 106 of the BR-101 highway in Sooretama.

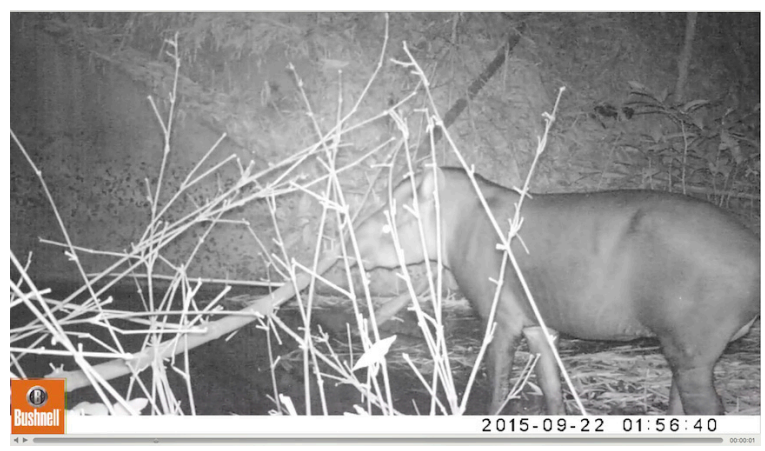

Video 2. Video of Lowland Tapir to cross the tunnel at km 120 of the BR-101 highway in Sooretama, which was blocked by fallen bamboo branches, on 22 September 2015.

between the 102 and $107 \mathrm{~km}$ stretch of the BR-101 that intercepts Sooretama, in both directions, using a hand-held speed camera (Bushnell ${ }^{\circledR}$ ). In addition, in February 2020, we measured speeds at km 102 and km 107. Measurements were conducted in the morning, afternoon, and evening on different days. The maximum speed limit allowed along the $23 \mathrm{~km}$ of the BR-101 that intercepts Sooretama is $80 \mathrm{~km} / \mathrm{h}$ (from km 101 to 102 and $\mathrm{km} 107$ to 124 ) or $60 \mathrm{~km} / \mathrm{h}$ (from km 102 to 107, the stretch that intercepts the SBR). From 2011 to 2017 there were electronic speed monitoring devices (radars) at the beginning and end of the $60 \mathrm{~km} / \mathrm{h}$ stretch, but in 2017, the radars were removed. The speed of 580 vehicles was measured in the $80 \mathrm{~km} / \mathrm{h}$ limit stretch of the BR-101 that intercepted Sooretama, 70\% of the vehicles exceeded the speed limit, the lowest recorded speed was $48 \mathrm{~km} / \mathrm{h}$, the highest recorded speed was $170 \mathrm{~km} / \mathrm{h}$, and the average speed was $92 \pm 20 \mathrm{~km} / \mathrm{h}$. In the $60 \mathrm{~km} / \mathrm{h}$ limit stretch, we measured the speed of 662 vehicles, of which $80 \%$ exceeded the speed limit, the lowest recorded speed was $36 \mathrm{~km} / \mathrm{h}$, the highest recorded speed was $138 \mathrm{~km} / \mathrm{h}$, and the average speed was $76 \pm 18 \mathrm{~km} / \mathrm{h}$. In February 2020, the speed of 40 
vehicles was measured between km 102 and 107, of which $87 \%$ exceeded the speed limit. Here, the lowest recorded speed was $54 \mathrm{~km} / \mathrm{h}$, the highest recorded speed was $132 \mathrm{~km} / \mathrm{h}$, and the average speed was $80 \pm 17$ $\mathrm{km} / \mathrm{h}$. The radars were reinstalled in 2021 and the speed limit was raised to $80 \mathrm{~km} / \mathrm{h}$, but we do not assess the speed of vehicles.

Wildlife-vehicle collisions are a huge threat against biodiversity, but they can also cause a great impact on human health and safety because they can result in serious accidents, which risk human health/life and come at high economic costs (Seiler 2005; Huijser et al. 2009; Freitas \& Barszcz 2015). For example, accidents with large-sized animals, such as tapirs, can result in serious human injury or death (Freitas \& Barszcz 2015). Between 2014 and 2020, over 30 human deaths occurred in accidents at $23 \mathrm{~km}$ of the BR-101 in Sooretama. However, it was not possible to confirm whether these accidents involved animals on the road. In a collision with a tapir in Sooretama (on 24 October 2014), the car driver obtained severe injuries and was hospitalized. The resulting costs from vehicle-animal collisions are high, but these accidents can be avoided or reduced by implementing mitigation measures that increase the safety of roads and reduce the damage caused by this type of accident (Huijser et al. 2009).

\section{Emergency measures}

The BR-101 poses one of the major threats to the biodiversity of the Sooretama region because of its negative effect on species. In addition, there are concerns about the duplication plan for the BR-101 highway, which could be implemented in the coming years, including the duplication of the stretch that intercepts the protected areas (Srbek-Araujo et al. 2015). Among the proposals to mitigate the impacts of the BR101 duplication, there is the construction of viaducts for cars and wildlife bridges, or the relocation of the vehicle flow to areas with a lower conservation priority (Srbek-Araujo et al. 2015). However, until the mitigation of the highway expansion is resolved, accidents will continue to kill animals, including lowland tapirs. Thus, due to pending permanent mitigation measures for the highway expansion, emergency measures must be taken to avoid wildlife accidents.

There are several commonly used mitigation measures for reducing wildlife-vehicle collisions (see Goosem et al. 2001; Clevenger 2005; Glista et al. 2009; van der Ree et al. 2009; Lesbarrères \& Fahrig 2012; van der Grift et al. 2013; Rytwinski et al. 2016), and high-cost mitigation measures are reported to be more effective in reducing accidents with large mammals (Rytwinski et al. 2016), although they require more planning and time to implement. However, some mitigation measures can be implemented quickly and without high costs, which would substantially reduce fatal accidents (Lester 2015). In 2014, during the workshop "Impactos da rodovia BR-101 na Reserva Biológica de Sooretama: Estudos, Alternativas e Mitigação", a multidisciplinary team of experts (see Últimos Refúgios 2014b) recommended the following emergency measures: (1) the maintenance of the drainage culverts to serve as wildlife passages; (2) the elimination of jackfruit trees Artocarpus heterophyllus, mango trees Mangifera indica, and other exotic fruit trees that grow on the margins of the highway and attract wildlife; (3) a speed limit reduction to $60 \mathrm{~km} / \mathrm{h}$ along the whole stretch; (4) the installation of speed bumps and electronic speed monitoring devices along the whole stretch; (5) the installation of warning signs informing about the possibility of wildlife crossings and risk of wildlife accidents; and (6) the monitoring of the effectiveness of the implemented mitigation measures (Universidade Federal do Espírito Santo 2014). The mitigation measures were discussed with the Federal Public Prosecution Ministry and agreed upon with the other regulatory bodies, including the National Land Transport Agency and Chico Mendes Institute for Biodiversity Conservation, as well as representatives of the company responsible for the highway administration. However, more than seven years have passed and only one recommendation has been implemented (the removal of fruit trees from km 119 to 123 in August 2018). If all measures had been implemented as proposed, fatal accidents involving wildlife that have occurred in the following years of the workshop could have been avoided. From the proposal of the measures until the conclusion of this article, an average of one tapir died per year.

We agree that the relocation of the BR-101 highway from Sooretama is the best measure to guarantee the conservation of the landscape and local biodiversity for the long term. Sooretama has a long history of protection that precedes the existence of the highway, with all administrative acts that guarantee its conservation documented (Instituto Chico Mendes de Conservação da Biodiversidade 2019; Instituto Brasileiro de Desenvolvimento Florestal 1981). The highway was built across the protected area in the late 1960s, even though this was prohibited by the Forest Code (Instituto Brasileiro de Desenvolvimento Florestal 1981). Furthermore, no documents were found that show the administrative act that allowed the construction of this 
highway within Sooretama. As a result, the preservation of the local biodiversity is jeopardized because one of Brazil's busiest highways crosses the interior of this protected areas complex.

\section{CONCLUSION}

The BR-101 highway represents a great threat for the conservation of the lowland tapir and many other species in the forest complex of Sooretama, one of the last regions that harbors viable tapir populations in the Atlantic Forest. The maintenance of tunnels used by fauna is necessary to mitigate the impact of road, but it is not a definitive solution for the fauna roadkill. In addition to the loss of biodiversity, vehicle collisions with tapirs result in risk to human life, economic losses, and loss of valuable ecological services. Emergency mitigation measures must be implemented to avoid further losses due to the chronic impact of the highway on biodiversity along the stretches that cross the protected areas of Sooretama region. Furthermore, we suggest building a detour to remove the BR-101 highway from within Sooretama.

\section{REFERENCES}

Alvares, C.A., J.L. Stape, P.C. Sentelhas, G. de Moraes, J. Leonardo \& G. Sparovek (2013). Köppen's climate classification map for Brazil. Meteorologische Zeitschrift 22: 711-728. https://doi. org/10.1127/0941-2948/2013/0507

Ascensão, F. \& A. Mira (2007). Factors affecting culvert use by vertebrates along two stretches of road in southern Portugal. Ecological Research 22: 57-66. https://doi.org/10.1007/s11284006-0004-1

Ascensão, F., A.L.J Desbiez, E.P. Medici \& A. Bager (2017). Spatia patterns of road mortality of medium-large mammals in Mato Grosso do Sul, Brazil. Wildlife Research 44: 135-146. https://doi. org/10.1071/wr16108

Banhos, A., B.L. Fontes, D.R. Yogui, M.H. Alves, N.C. Ardente, R. Valls, L.M. Barreto, L. Damásio, Á.C. Ferreguetti, A.S. Carvalho, V.R. Schettino, A.R. Santos, H.G. Bergallo, A.C. Srbek-Araujo, E.P. Medici \& A.L.J. Desbie (2020). Highways are a threat for giant armadillos that underpasses can mitigate. Biotropica 52: 421-426. https://doi.org/10.1111/btp.12778

Barcelos, A.R., P.E.D. Bobrowiec, T.M. Sanaiotti \& R. Gribe (2013). Seed germination from lowland tapir (Tapirus terrestris) fecal samples collected during the dry season in the northern Brazilian Amazon. Integrative Zoology 8: 63-73. https://doi. org/10.1111/1749-4877.12003

Bello, C., M. Galetti, M.A. Pizo, L.F.S. Magnago, M.F. Rocha, R.A.F. Lima, C.A. Peres, O. Ovaskainen \& P. Jordano (2015). Defaunation affects carbon storage in tropical forests. Science Advances 1: 1-11. https://doi.org/10.1126/sciadv.1501105

Bueno, R.S., R. Guevara, M.C. Ribeiro, L. Culot, F.S. Bufalo \& M. Galetti (2013). Functional redundancy and complementarities of seed dispersal by the last neotropical megafrugivores. PLOS ONE 8(2): e56252. https://doi.org/10.1371/journal.pone.0056252
Cáceres, N.C. (2011). Biological characteristics influence mammal road kill in an Atlantic Forest-Cerrado interface in south-western Brazil. Italian Journal of Zoology 78: 379-389. https://doi.org/10.1080/11 250003.2011.566226

Cáceres, N.C., W. Hannibal, D.R. Freitas, E.L. Silva, C. Roman \& J. Casella (2010). Mammal occurrence and roadkill in two adjacent ecoregions (Atlantic Forest and Cerrado) in south-western Brazil. Zoologia (Curitiba) 27: 709-717. https://doi.org/10.1590/S198446702010000500007

Cain, A.T., V.R. Tuovila, D.G. Hewitt \& M.E. Tewes (2003). Effects of a highway and mitigation projects on bobcats in Southern Texas. Biological Conservation 114: 189-197. https://doi.org/10.1016/ S0006-3207(03)00023-5

Carvalho, A.S., F.D. Martins, F.M. Dutra, D. Gettinger, F. MartinsHatano \& H.G. Bergallo (2014). List Large and Medium-Sized Mammals of Carajás National, Pará State, Brazil. Check List 10: 1-9. https://doi.org/10.15560/10.1.1

Clevenger, A.P. (2005). Conservation value of wildlife crossings: Measures of performance and research directions. Gaia 14: 124129. https://doi.org/10.14512/gaia.14.2.12

Clevenger, A.P., B. Chruszcz \& K. Gunson (2001). Drainage culverts as habitat linkages and factors affecting passage by mammals. Journal of Applied Ecology 38: 1340-1349. https://doi.org/10.1046/j.00218901.2001.00678.x

Coffin, A.W. (2007). From roadkill to road ecology: A review of the ecological effects of roads. Journal of Transport Geography 15: 396406. https://doi.org/10.1016/j.jtrangeo.2006.11.006

Damásio, L., L.A. Ferreira, V.T. Pimenta, G.G. Paneto, A.R. dos Santos, A.D. Ditchfield, H.G. Bergallo \& A. Banhos (2021). Diversity and Abundance of Roadkilled Bats in the Brazilian Atlantic Forest. Diversity 13: 335. https://doi.org/10.3390/d13070335

de Freitas, M.A., R.C. Printes, E.K. Motoyama, A.E. Fucks \& D. Veríssimo (2017). Roadkill records of Lowland Tapir Tapirus terrestris (Mammalia: Perissodactyla: Tapiridae) between kilometers 06 and 76 of highway BR-163, state of Pará, Brazil. Journal of Threatened Taxa 9(11): 10948-10952. https://doi.org/10.11609/ jott.3227.9.11.10948-10952

de Souza, J.C., V.P. da Cunha \& S.H. Markwith (2015). Spatiotemporal variation in human-wildlife conflicts along highway BR-262 in the Brazilian Pantanal. Wetlands Ecology and Management 23: 227239. https://doi.org/10.1007/s11273-014-9372-4

Dodd, Jr. C.K., W.J. Barichivich \& L.L. Smith (2004). Effectiveness of a barrier wall and culverts in reducing wildlife mortality on a heavily traveled highway in Florida. Biological Conservation 118: 619-631. https://doi.org/10.1016/j.biocon.2003.10.011

Eisenberg, J.F. \& K.H. Redford (1999). Mammals of the Neotropics, Volume 3: Ecuador, Bolivia, Brazil. University of Chicago Press, Illinois. https://doi.org/10.4067/S0716-078X2005000200017

Fahrig, L. \& T. Rytwinski (2009). Effects of Roads on Animal Abundance: an Empirical Review and Synthesis. Ecology and Society 14: 21. http://www.ecologyandsociety.org/vol14/iss1/art21/ Electronic version accessed 20 May 2020.

Ferreguetti, A.C., W.M. Tomás \& H.G. Bergallo (2017). Density, occupancy, and detectability of lowland tapirs, Tapirus terrestris, in Vale Natural Reserve, southeastern Brazil. Journal of Mammalogy 98: 114-123. https://doi.org/10.1093/jmammal/gyw118

Flesher, K.M. \& A. Gatti (2010). Tapirus terrestris in Espírito Santo, Brasil. Tapir Conservation 19/1: 16-23.

Forman, R.T.T. \& L.E. Alexander (1998). Roads and their major ecological effects. Annual Review of Ecology and Systematics 29: 207-231. https://doi.org/10.1146/annurev.ecolsys.29.1.207

Freitas, S.R. \& L.B. Barszcz (2015). A perspectiva da mídia online sobre os acidentes entre veículos e animais em rodovias brasileiras: uma questão de segurança? Desenvolvimento e Meio Ambiente 33: 261276. https://doi.org/10.5380/dma.v33i0.36910

Galetti, M., H.C. Giacomini, R.S. Bueno, C.S.S. Bernardo, R.M. Marques, R.S. Bovendorp, C.E. Steffler, P. Rubim, S.K. Gobbo, C.I. Donatti, R.A. Begotti, F. Meirelles, R.A. Nobre, A.G. Chiarello \& C.A. Peres (2009). Priority areas for the conservation of Atlantic forest 
large mammals. Biological Conservation 142: 1229-1241. https:// doi.org/10.1016/j.biocon.2009.01.023

García, M.J., E.P. Medici, E.J. Naranjo, W. Novarino \& R.S. Leonardo (2012). Distribution, habitat and adaptability of the genus Tapirus. Integrative Zoology 7: 346-355. https://doi.org/10.1111/j.17494877.2012.00317.x

Gatti, A., D. Brito \& S.L. Mendes (2011). How many lowland tapirs (Tapirus terrestris) are needed in Atlantic Forest fragments to ensure long- term persistence? Studies on Neotropical Fauna and Environment 46: 77-84. https://doi.org/10.1080/01650521.2011.5 62086

Giombini, M.I., S.P. Bravo \& D.S. Tosto D.S. (2016). The key role of the largest extant Neotropical frugivore (Tapirus terrestris) in promoting admixture of plant genotypes across the landscape. Biotropica 48: 499-508. https://doi.org/10.1111/btp.12328

Glista, D.J., T.L. DeVault \& J.A. DeWoody (2009). A review of mitigation measures for reducing wildlife mortality on roadways. Landscape and Urban Planning 91: 1-7. https://doi.org/10.1016/j. landurbplan.2008.11.001

Goosem, M., Y. Izumi \& S. Turton (2001). Efforts to restore habitat connectivity for an upland tropical rainforest fauna: A trial of underpasses below roads. Ecological Management \& Restoration 2 196-202. https://doi.org/10.1046/j.1442-8903.2001.00084.x

Grilo, C., M.R.Coimbra, R.C. Cerqueira, P. Barbosa, R.A.P. Dornas, L.O. Gonçalves, F.Z. Teixeira, I.P. Coelho, B.R. Schmidt, D.L.K. Pacheco, G. Schuck, I.B. Esperando, J.A. Anza, J. Beduschi, N.R. Oliveira, P.F. Pinheiro, A. Bager, H. Secco, M. Guerreiro, C.F. Carvalho, A.C. Veloso, A.E.I. Custódio, O. Marçal, G. Ciocheti, J. Assis, M.C. Ribeiro, B.S.S. Francisco, J.J. Cherem, T.C. Trigo, M.M.A. Jardim, I.C. Franceschi, C. Espinosa, F.P. Tirelli, V.J. Rocha, M.L. Sekiama, G.P. Barbosa, H.R. Rossi, T.C. Moreira, M. Cervini, C.A. Rosa, L.G. Silva, C.M.M. Ferreira, A. César, J. Casella, S.L. Mendes, J. Zina, D.F.O. Bastos, R.A.T. Souza, P.A. Hartmann, A.C.G. Deffaci, J. Mulinari, S.C. Luzzi, T. Rezzadori, C. Kolcenti, T.X. Reis, V.S.C. Fonseca, C.F. Giorgi, R.P.Migliorini, C.B. Kasper, C. Bueno, M. Sobanski, A.P.F.G. Pereira, F.A.G. Andrade, M.E.B. Fernandes, L.L.C. Corrêa, A. Nepomuceno, A. Banhos, W. Hannibal, R. Fonseca, L.A. Costa, E.P. Medici, A. Croce, K. Werther, J.P. Oliveira, J.M Ribeiro, M. de Santi, A.E. Kawanami, L. Perles, C. do Couto, D.S. Figueiró, E. Eizirik, A.A. Correia, F.M. Corrêa, D. Queirolo, A.L. Quagliatto, B.H. Saranholi, P.M. Galetti, K.G. Rodriguez-Castro, V.S. Braz, F.G.R. França, G. Buss, J.A. Rezini, M.B. Lion, C.C. Cheida, A.C.R. Lacerda, C.H. Freitas, F. Venâncio, C.H. Adania, A.F. Batisteli, C.G.Z. Hegel, J.A. Mantovani, F.H.G. Rodrigues, T. Bagatini, N.H.A. Curi, L. Emmert, R.H. Erdmann, R.R.G.F. Costa, A. Martinelli, C.V.F. Santos \& A. Kindel (2018). Brazil road-kill: a data set of wildlife terrestrial vertebrate road-kills. Ecology 99: 2625. https://doi.org/10.1002/ ecy. 2464

Holderegger, R. \& M. Di Giulio (2010). The genetic effects of roads: A review of empirical evidence. Basic and Applied Ecology 11: 522531. https://doi.org/10.1016/j.baae.2010.06.006

Huijser, M.P., J.W. Duffield, A.P. Clevenger, R.J. Ament \& P.T. McGowen (2009). Cost-benefit analysis of mitigation measures aimed at reducting collisions with large ungulates in the United States and Canada, a decision support tool. Ecology and Society 14: 15. http://www.ecologyandsociety.org/vol14/iss2/art15/ Electronic version accessed 20 May 2020

Instituto Brasileiro de Desenvolvimento Florestal (1981). Plano de Manejo Reserva Biológica de Sooretama. http://www.icmbio. gov.br/portal/images/stories/docs-planos-de-manejo/rebio_ sooretama_pm.pdf Electronic version accessed 13 March 2019.

Instituto Chico Mendes de Conservação da Biodiversidade (2019). Plano de Manejo Reserva Biológica de Sooretama. https://www.icmbio.gov.br/portal/images/stories/docs-planosde-manejo/plano_de_manejo_rebio_sooretama_2020.pdf Electronic version accessed 20 May 2020.

Klippel, A.H., P.V. Oliveira, K.B. Britto, B.F. Freire, M.R. Moreno, A.R. Santos, A. Banhos \& G.G. Paneto (2015). Using DNA barcodes to identify road-killed animals in two Atlantic Forest nature reserves,
Brazil. PLoS One 10: e0134877. https://doi.org/10.1371/journal. pone.0134877

Laurance, W.F., M. Goosem \& S.G.W.W. Laurance (2009). Impacts of roads and linear clearings on tropical forests. Trends in Ecology \& Evolution 24: 659-669. https://doi.org/10.1016/j.tree.2009.06.009

Lesbarrères, D. \& L. Fahrig (2012). Measures to reduce population fragmentation by roads: what has worked and how do we know? Trends in Ecology \& Evolution 27: 374-380. https://doi. org/10.1016/j.tree.2012.01.015

Lester, D. (2015). Effective Wildlife Roadkill Mitigation. Journal of Traffic and Transportation Engineering 3: 42-51. https://doi. org/10.17265/2328-2142/2015.01.005

Lorenzutti, R. \& A.P. Almeida (2006). A coleção de mamíferos do Museu Elias Lorenzutti em Linhares, Estado do Espírito Santo, Brasil. Boletim do Museu de Biologia Mello Leitão (Nova Série) 19: 59-74.

McCollister, M.F. \& F.T. van Manen (2010). Effectiveness of Wildlife Underpasses and Fencing to Reduce Wildlife-Vehicle Collisions. The Journal of Wildlife Management 74: 1722-1731. https://doi. org/10.2193/2009-535

Medici, E.P. (2011). Family Tapiridae (Tapirs), pp. 182-204. In: Wilson, D.E. \& R.A. Mittermeier (eds.). Handbook of the Mammals of the World: Vol. 2: Hoofed Mammals. Lynx Edicions, Barcelona. https:// doi.org/10.1515/mammalia-2012-0032

Medici, E.P. \& A.L.J. Desbiez (2012). Population viability analysis: using a modeling tool to assess the viability of tapir populations in fragmented landscapes. Integrative Zoology 7(4): 356-372. https:// doi.org/10.1111/j.1749-4877.2012.00318.x

Medici, E.P., K. Flesher, B.M. Beisiegel, A. Keuroghlian, A.L.J. Desbiez, A. Gatti, A.R.M. Pontes, C.B. de Campos, C.F. de Tófoli, E.A. Moraes Junior, F.C. de Azevedo, G.M. de Pinho, J.L.P. Cordeiro, T.S. Santos Júnior, A.A. de Morais, P.R. Mangini, L.F. Rodrigues \& L.B. de Almeida (2012). Avaliação do Risco de Extinção da Anta brasileira Tapirus terrestris Linnaeus, 1758, no Brasil. Biodiversidade Brasileira-BioBrasil Ano II: 103-116.

Medici, E.P., K. Flesher, B.M. Beisiegel, A. Keuroghlian, A.L.J. Desbiez, A. Gatti, A.R.M. Pontes, C.B. de Campos, C.F. de Tófoli, E.A. Moraes Junior, F.C. de Azevedo, G.M. de Pinho, J.L.P. Cordeiro, T.S. Santos Júnior, A.A. de Morais, P.R. Mangini, L.F. Rodrigues \& L.B. de Almeida (2018). Tapirus terrestris (Linnaeus, 1758), pp. 5968. In: Instituto Chico Mendes de Conservação da Biodiversidade (ed.). Livro Vermelho da Fauna Brasileira Ameaçada de Extinção: Vol 2: Mamíferos. Instituto Chico Mendes de Conservação da Biodiversidade, Brasília.

Myers, N., R.A. Mittermeier, C.G. Mittermeier, G.A. da Fonseca \& J. Kent (2000). Biodiversity hotspots for conservation priorities. Nature 403: 853-858. https://doi.org/10.1038/35002501

Padilla, M. \& R.C. Dowler (1994). Tapirus terrestris. Mammalian Species 481: 1-8. https://doi.org/10.2307/3504109

Paolucci, L.N., R.L. Pereira, L. Rattis, D.V. Silvério, N.C.S. Marques, M.N. Macedo \& P.M. Brando (2019). Lowland tapirs facilitate seed dispersal in degraded Amazonian forests. Biotropica 51: 245-252. https://doi.org/10.1111/btp.12627

Peres, C.A., E. Thaise, J. Schietti, S.J.M. Desmoulieres \& T. Levi (2015). Dispersal limitation induces long-term biomass collapse in overhunted Amazonian forests. Proceedings of the National Academy of Sciences USA 113: 892-897. https://doi.org/10.1073/ pnas.1516525113

van der Ree, R., D. Heinze, M. McCarthy \& I. Mansergh (2009). Wildlife tunnel enhances population viability. Ecology and Society 14: 7. http://www.ecologyandsociety.org/vol14/iss2/art7/ Electronic version accessed 20 May 2020.

Ribeiro, M.C., J.P. Metzger, A.C. Martensen, F.J. Ponzoni \& M.M. Hirota (2009). The Brazilian Atlantic Forest: How much is left, and how is the remaining forest distributed? Implications for conservation. Biological Conservation 142: 1141-1153. https://doi. org/10.1016/j.biocon.2009.02.021

Rolim, S.G., L.F.T. Menezes \& A.C. Srbek-Araujo (2016). Floresta Atlântica de Tabuleiro: Diversidade e Endemismo na Reserva Natural Vale. Editora Rona, Belo Horizonte. 
Rytwinski, T., K. Soanes, J.A.G. Jaeger, L. Fahrig, C.S. Findlay, J. Houlahan, R. van der Ree \& E.A. van der Grift (2016). How effective is road mitigation at reducing road-kill? A meta-analysis. PLoS One 11: 1-25. https://doi.org/10.1371/journal.pone.0166941

Seiler, A. (2005). Predicting locations of moose-vehicle collisions in Sweden. Journal of Applied Ecology 42: 371-382. https://doi. org/10.1111/j.1365-2664.2005.01013.x

Srbek-Araujo, A.C., S.L. Mendes \& A.G. Chiarello (2015). Jaguar (Panthera onca Linnaeus, 1758) roadkill in Brazilian Atlantic Forest and implications for species conservation. Brazilian Journal of Biology 75: 581-586. https://doi.org/10.1590/1519-6984.17613

Taylor, B.D. \& R.L. Goldingay (2003). Cutting the carnage: wildlife usage of road culverts in north-eastern New South Wales. Wildlife Research 30: 529-537. https://doi.org/10.1071/WR01062

Trombulak, S.C. \& C.A. Frissell (2000). Review of Ecological Effects of Roads on Terrestrial and Aquatic Communities. Conservation Biology 14: 18-30. https://doi.org/10.1046/j.1523-1739.2000.99084.x

Últimos Refúgios (2014a). Riquezas Perdidas.
Electronic version accessed 20 May 2020. https://youtu.be/ yv2t5qQVAPk
Últimos Refúgios (2014b). Workshop - Impactos da Rodovia BR-101 na Reserva Biológica de Sooretama. https://youtu.be/XQI2VPPqAcg Electronic version accessed 20 May 2020.

Últimos Refúgios (2015) Uma Estrada no Caminho. Electronic version accessed 20 May 2020. https://youtu.be/U6io6QdAVhQ

Universidade Federal do Espírito Santo (2014). Workshop Impactos da Rodovia BR-101 na Reserva Biológica de Sooretama: Estudos, Alternativas e Mitigação. https://06860d25-8838-49fb-9e43af80dd7048f1.filesusr.com/ugd/1573a4_68a84628f9dc4e8594b73 e3698f3e368.pdf (accessed 20 May 2020).

van der Grift, E.A., R. van der Ree, L. Fahrig, S. Findlay, J. Houlahan, J.A.G. Jaeger, N. Klar, L.F. Madriñan \& L. Olson (2013). Evaluating the effectiveness of road mitigation measures. Biodiversity and Conservation 22: 425-448. https://doi.org/10.1007/s10531-0120421-0

Varela, D., K. Flesher, J. Cartes, S. Chalukian, S. de Bustos, G. Ayala \& C. Richard-Hansen (2019). Tapirus terrestris, Lowland Tapir. The IUCN Red List of Threatened Species 2019. https://doi.org/10.2305/ IUCN.UK.2019-1.RLTS.T21474A45174127.en

Resumo (Português): As rodovias limitam a movimentação e a dispersão de animais silvestres e contribuem para a perda de indivíduos por atropelamento, levando o isolamento e ao declínio das populações, aumentando o risco de extinção local. A anta brasileira Tapirus terrestris é o maior herbívoro-frugívoro neotropical e apesar de sua ampla distribuição na América do Sul, está ameaçada de extinção. Neste estudo, nós relatamos seis eventos de atropelamento de antas, entre 2014 e 2019, em um trecho de rodovia federal BR-101 que intercepta um mosaico de reservas da Mata Atlântica, denominado Sooretama, um dos últimos refúgios de antas no sudeste do Brasil. 0 tráfego de veículos nesta área é intenso, com controle inadequado de velocidade, enquanto árvores frutíferas exóticas crescem ao longo da rodovia atraindo animais silvestres. Túneis de drenagem de água servem de passagem para algumas espécies, incluindo antas. No entanto, os túneis localizados sob a rodovia não recebem manutenção periódica adequada, reduzindo sua efetividade. A perda de pelo menos uma anta por ano pode ter consequências graves a longo prazo para uma das últimas populações viáveis de anta brasileira em toda a Mata Atlântica. Assim, medidas emergenciais são necessárias para evitar colisões entre veículos e antas.

Author details: AuREo BANHOS is Associate Professor at Espírito Santo Federal University. His research is focused on Conservation Biology, using genetic, ecological and evolutionary tools to investigate wildlife and generate results applied to environmental management and policy. ANDRESSA GATTI is a researcher fellow of National Institute of the Atlantic Forest-INMA and executive director of Pró-Tapir Institute for Biodiversity, working mainly with ecology and conservation of mammals and their habitats, extinction risk, human-wildlife coexistence, and scientific outreach. MARCELO RENAN DE DEUS SANTOS is a veterinarian and ecologist. His focus is on wildlife conservation, monitoring the health of wild animals under the vision of One Health, development, and execution of conservation projects. He is the president of Instituto Marcos Daniel, where he coordinates the Chelonia mydas project and the Cherry-throated Tanager conservation program. LEONARDo MERçON is a wildlife photographer, graphic designer, and director of Instituto Últimos Refúgios (Last Refuges). ILKA WESTERMEYER is an international manager, and wildlife moviemaker, and director of Instituto Últimos Refúgios (Last Refuges). NATÁLIA CARNEIRO ARDENTE is a biologist and ecologist. Her focus is on wildlife conservation, mainly mammals. LUIS Franscisco Oliveira Pereira Gonzaga is a biologist and currently is attending post-graduation in animal biology. He works as biology teacher, field biologist, and wildlife photographer. LUCAS MENDES BARRETO is a biologist, master in tropical biodiversity, experience in road ecology, monitoring and rescue of fauna and environmental education. Currently, he coordinates the field activities of the Armadillo Conservation Project in the Atlantic Forest. LUCAS DAMÁsı is a biologist and ecologist. Currently, he works as an Environmental Analyst. TOMAS DE LIMA ROCHA is a biologist and zoologist, with emphasis on road ecology and herpetology. VITOR ROBERTO SCHETTINO is a geologist and experienced in geotechnologies. RENATA VALLS is a biologist and ecologist. Her research is focuses on landscape ecology and mammals ecology. HelenA Godoy Bergallo is Associate Professor at Rio de Janeiro State University and coordinates the Atlantic Forest Biodiversity Research Network program of the Ministry of Science, Technology and Innovation, working in research, training, scientific dissemination and data availability. Her research focuses on natural history, mammal ecology and anthropogenic impacts. MARcos VINícIUS FreITAS SILVA is a biologist. His research is focused on plastination and biological conservation of vertebrates in biological collections, working as intern in Plastination Laboratory from Espírito Santo Federal University. ATHELSON STEFANON BITTENCOURT is a biologist and physiologist, and coordinator of the of the Museu de Ciências da Vida (Museum of Life Sciences) and the Plastination Laboratory from Espírito Santo Federal University. DANIELLE DE O. MOREIRA is a researcher fellow of National Institute of the Atlantic Forest-INMA. Her research is focused on ecology of mammals, ecological niche modeling, extinction risk, human-wildlife coexistence, and history of zoology. ANA CAROLINA SRBEK-ARAUIO is Titular Professo at Universidade Vila Velha. Her research is focused on ecology and conservation of vertebrates, especially mammals, working mainly with population ecology, trophic ecology, and activity pattern.

Author contributions: Conceptualization, A.B., A.G., M.R.d.D.S, L.M. and I.W.; methodology, A.B., A.G., M.R.d.D.S., N.C.A., H.G.B. and A.C.S.A.; formal analysis, A.B. A.G., M.R.d.D.S., N.C.A., L.F.O.P.G, V.R.S., R.V., H.G.B. and A.C.S.A; investigation, A.B., A.G., M.R.d.D.S., L.M., I.W., N.C.A., L.F.O.P.G, L.M.B., L.D., T.L.R., V.R.S., R.V., H.G.B., M.V.F.S, A.S.B., D.O.M. and A.C.S.A.; resources, A.B., A.G., M.R.d.D.S., H.G.B., A.S.B., and A.C.S.A.; data curation, A.B., A.G., and M.R.d.D.S.; writing-original draft preparation, A.B., A.G., M.R.d.D.S., N.C.A., H.G.B., D.O.M. and A.C.S.A.; writing-review and editing, A.B., A.G., M.R.d.D.S., L.F.O.P.G, H.G.B., D.O.M. and A.C.S.A.; visualization, A.B., A.G., M.R.d.D.S., L.M., I.W., N.C.A., L.F.O.P.G, L.M.B., L.D., T.L.R., V.R.S., R.V., H.G.B., M.V.F.S, A.S.B., D.O.M. and A.C.S.A.; supervision, A.B.; funding acquisition, A.B., H.G.B. and A.C.S.A..

Acknowledgements: We would like to thank the Chico Mendes Institute for Biodiversity Conservation for the permission to collect biological samples in the Sooretama Biological Reserve (number SISBIO 45446-3). Furthermore, we would like to thank the SBR director, Eliton Lima, and the environmental analysts, Valdir Martins and Marcel Redling Moreno. We also thank our helpers: Yhuri Nóbrega, Alexandre Bastos, Bárbara Fonseca Dias, Brener Fabres, Fabiana Mendonça Cruz, Genilson Tadeu Silva Junior, Jardel Brandão Seibert, Juliana Krüger Arpini, Maria Alice Moreira Machado, Moara Cuzzuol Gomes, Paula Modenesi Ferreira, Savio Augusto de Souza Machado, and Thaís Cordeiro Sathler Sperandio. Finally, we would like to thank Alexandre Rosa dos Santos and Eduardo de Sá Mendonça, from the Federal University of Espírito Santo. This study is part of a research program in biodiversity (PPBio MA). 

Dr. John Noyes, Natural History Museum, London, UK

Dr. Albert G. Orr, Griffith University, Nathan, Australia

Dr. Sameer Padhye, Katholieke Universiteit Leuven, Belgium

Dr. Nancy van der Poorten, Toronto, Canada

Dr. Kareen Schnabel, NIWA, Wellington, New Zealand

Dr. R.M. Sharma, (Retd.) Scientist, Zoological Survey of India, Pune, India

Dr. Manju Siliwal, WILD, Coimbatore, Tamil Nadu, India

Dr. G.P. Sinha, Botanical Survey of India, Allahabad, India

Dr. K.A. Subramanian, Zoological Survey of India, New Alipore, Kolkata, India

Dr. P.M. Sureshan, Zoological Survey of India, Kozhikode, Kerala, India

Dr. R. Varatharajan, Manipur University, Imphal, Manipur, India

Dr. Eduard Vives, Museu de Ciències Naturals de Barcelona, Terrassa, Spain

Dr. James Young, Hong Kong Lepidopterists' Society, Hong Kong

Dr. R. Sundararaj, Institute of Wood Science \& Technology, Bengaluru, India

Dr. M. Nithyanandan, Environmental Department, La Ala Al Kuwait Real Estate. Co. K.S.C.,

Kuwait

Dr. Himender Bharti, Punjabi University, Punjab, India

Mr. Purnendu Roy, London, UK

Dr. Saito Motoki, The Butterfly Society of Japan, Tokyo, Japan

Dr. Sanjay Sondhi, TITLI TRUST, Kalpavriksh, Dehradun, India

Dr. Nguyen Thi Phuong Lien, Vietnam Academy of Science and Technology, Hanoi, Vietnam

Dr. Nitin Kulkarni, Tropical Research Institute, Jabalpur, India

Dr. Robin Wen Jiang Ngiam, National Parks Board, Singapore

Dr. Lional Monod, Natural History Museum of Geneva, Genève, Switzerland.

Dr. Asheesh Shivam, Nehru Gram Bharti University, Allahabad, India

Dr. Rosana Moreira da Rocha, Universidade Federal do Paraná, Curitiba, Brasi

Dr. Kurt R. Arnold, North Dakota State University, Saxony, Germany

Dr. James M. Carpenter, American Museum of Natural History, New York, USA

Dr. David M. Claborn, Missouri State University, Springfield, USA

Dr. Kareen Schnabel, Marine Biologist, Wellington, New Zealand

Dr. Amazonas Chagas Júnior, Universidade Federal de Mato Grosso, Cuiabá, Brasil

Mr. Monsoon Jyoti Gogoi, Assam University, Silchar, Assam, India

Dr. Heo Chong Chin, Universiti Teknologi MARA (UiTM), Selangor, Malaysia

Dr. R.J. Shiel, University of Adelaide, SA 5005, Australia

Dr. Siddharth Kulkarni, The George Washington University, Washington, USA

Dr. Priyadarsanan Dharma Rajan, ATREE, Bengaluru, India

Dr. Phil Alderslade, CSIRO Marine And Atmospheric Research, Hobart, Australia

Dr. John E.N. Veron, Coral Reef Research, Townsville, Australia

Dr. Daniel Whitmore, State Museum of Natural History Stuttgart, Rosenstein, Germany.

Dr. Yu-Feng Hsu, National Taiwan Normal University, Taipei City, Taiwan

Dr. Keith V. Wolfe, Antioch, California, USA

Dr. Siddharth Kulkarni, The Hormiga Lab, The George Washington University, Washington,

D.C., USA

Dr. Tomas Ditrich, Faculty of Education, University of South Bohemia in Ceske

Budejovice, Czech Republic

Dr. Mihaly Foldvari, Natural History Museum, University of Oslo, Norway

Dr. V.P. Uniyal, Wildlife Institute of India, Dehradun, Uttarakhand 248001, India

Dr. John T.D. Caleb, Zoological Survey of India, Kolkata, West Bengal, India

Dr. Priyadarsanan Dharma Rajan, Ashoka Trust for Research in Ecology and the Environment

(ATREE), Royal Enclave, Bangalore, Karnataka, India

\section{Fishes}

Dr. Neelesh Dahanukar, IISER, Pune, Maharashtra, India

Dr. Topiltzin Contreras MacBeath, Universidad Autónoma del estado de Morelos, México

Dr. Heok Hee Ng, National University of Singapore, Science Drive, Singapore

Dr. Rajeev Raghavan, St. Albert's College, Kochi, Kerala, India

Dr. Robert D. Sluka, Chiltern Gateway Project, A Rocha UK, Southall, Middlesex, UK

Dr. E. Vivekanandan, Central Marine Fisheries Research Institute, Chennai, India

Dr. Davor Zanella, University of Zagreb, Zagreb, Croatia

Dr. A. Biju Kumar, University of Kerala, Thiruvananthapuram, Kerala, India

Dr. Akhilesh K.V., ICAR-Central Marine Fisheries Research Institute, Mumbai Research

Centre, Mumbai, Maharashtra, India

Dr. J.A. Johnson, Wildlife Institute of India, Dehradun, Uttarakhand, India

Amphibians

Dr. Sushil K. Dutta, Indian Institute of Science, Bengaluru, Karnataka, India

Dr. Annemarie Ohler, Muséum national d'Histoire naturelle, Paris, France

\section{Reptiles}

Dr. Gernot Vogel, Heidelberg, Germany

Dr. Raju Vyas, Vadodara, Gujarat, India

Dr. Pritpal S. Soorae, Environment Agency, Abu Dubai, UAE.

Prof. Dr. Wayne J. Fuller, Near East University, Mersin, Turkey

Prof. Chandrashekher U. Rivonker, Goa University, Taleigao Plateau, Goa. India

Dr. S.R. Ganesh, Chennai Snake Park, Chennai, Tamil Nadu, India

Dr. Himansu Sekhar Das, Terrestrial \& Marine Biodiversity, Abu Dhabi, UAE
Birds

Dr. Hem Sagar Baral, Charles Sturt University, NSW Australia

Dr. Chris Bowden, Royal Society for the Protection of Birds, Sandy, UK

Dr. Priya Davidar, Pondicherry University, Kalapet, Puducherry, India

Dr. J.W. Duckworth, IUCN SSC, Bath, UK

Dr. Rajah Jayapal, SACON, Coimbatore, Tamil Nadu, India

Dr. Rajiv S. Kalsi, M.L.N. College, Yamuna Nagar, Haryana, India

Dr. V. Santharam, Rishi Valley Education Centre, Chittoor Dt., Andhra Pradesh, India

Dr. S. Balachandran, Bombay Natural History Society, Mumbai, India

Mr. J. Praveen, Bengaluru, India

Dr. C. Srinivasulu, Osmania University, Hyderabad, India

Dr. K.S. Gopi Sundar, International Crane Foundation, Baraboo, USA

Dr. Gombobaatar Sundev, Professor of Ornithology, Ulaanbaatar, Mongolia

Prof. Reuven Yosef, International Birding \& Research Centre, Eilat, Israel

Dr. Taej Mundkur, Wetlands International, Wageningen, The Netherlands

Dr. Carol Inskipp, Bishop Auckland Co., Durham, UK

Dr. Tim Inskipp, Bishop Auckland Co, Durham, UK

Dr. V. Gokula, National College, Tiruchirappalli, Tamil Nadu, India

Dr. Arkady Lelej, Russian Academy of Sciences, Vladivostok, Russia

Dr. Simon Dowell, Science Director, Chester Zoo, UK

Dr. Mário Gabriel Santiago dos Santos, Universidade de Trás-os-Montes e Alto Douro,

Quinta de Prados, Vila Real, Portugal

Dr. Grant Connette, Smithsonian Institution, Royal, VA, USA

Dr. M. Zafar-ul Islam, Prince Saud Al Faisal Wildlife Research Center, Taif, Saudi Arabia

Mammals

Dr. Giovanni Amori, CNR - Institute of Ecosystem Studies, Rome, Italy

Dr. Anwaruddin Chowdhury, Guwahati, India

Dr. David Mallon, Zoological Society of London, UK

Dr. Shomita Mukherjee, SACON, Coimbatore, Tamil Nadu, India

Dr. Angie Appel, Wild Cat Network, Germany

Dr. P.O. Nameer, Kerala Agricultural University, Thrissur, Kerala, India

Dr. Ian Redmond, UNEP Convention on Migratory Species, Lansdown, UK

Dr. Heidi S. Riddle, Riddle's Elephant and Wildlife Sanctuary, Arkansas, USA

Dr. Karin Schwartz, George Mason University, Fairfax, Virginia.

Dr. Lala A.K. Singh, Bhubaneswar, Orissa, India

Dr. Mewa Singh, Mysore University, Mysore, India

Dr. Paul Racey, University of Exeter, Devon, UK

Dr. Honnavalli N. Kumara, SACON, Anaikatty P.O., Coimbatore, Tamil Nadu, India

Dr. Nishith Dharaiya, HNG University, Patan, Gujarat, India

Dr. Spartaco Gippoliti, Socio Onorario Società Italiana per la Storia della Fauna "Giuseppe

Altobello", Rome, Italy

Dr. Justus Joshua, Green Future Foundation, Tiruchirapalli, Tamil Nadu, India

Dr. H. Raghuram, The American College, Madurai, Tamil Nadu, India

Dr. Paul Bates, Harison Institute, Kent, UK

Dr. Jim Sanderson, Small Wild Cat Conservation Foundation, Hartford, USA

Dr. Dan Challender, University of Kent, Canterbury, UK

Dr. David Mallon, Manchester Metropolitan University, Derbyshire, UK

Dr. Brian L. Cypher, California State University-Stanislaus, Bakersfield, CA

Dr. S.S. Talmale, Zoological Survey of India, Pune, Maharashtra, India

Prof. Karan Bahadur Shah, Budhanilakantha Municipality, Kathmandu, Nepal

Dr. Susan Cheyne, Borneo Nature Foundation International, Palangkaraja, Indonesia

Dr. Hemanta Kafley, Wildlife Sciences, Tarleton State University, Texas, USA

\section{Other Disciplines}

Dr. Aniruddha Belsare, Columbia MO 65203, USA (Veterinary)

Dr. Mandar S. Paingankar, University of Pune, Pune, Maharashtra, India (Molecular)

Dr. Jack Tordoff, Critical Ecosystem Partnership Fund, Arlington, USA (Communities)

Dr. Ulrike Streicher, University of Oregon, Eugene, USA (Veterinary)

Dr. Hari Balasubramanian, EcoAdvisors, Nova Scotia, Canada (Communities)

Dr. Rayanna Hellem Santos Bezerra, Universidade Federal de Sergipe, São Cristóvão, Brazil

Dr. Jamie R. Wood, Landcare Research, Canterbury, New Zealand

Dr. Wendy Collinson-Jonker, Endangered Wildlife Trust, Gauteng, South Africa

Dr. Rajeshkumar G. Jani, Anand Agricultural University, Anand, Gujarat, India

Dr. O.N. Tiwari, Senior Scientist, ICAR-Indian Agricultural Research Institute (IARI), New

Delhi, India

Dr. L.D. Singla, Guru Angad Dev Veterinary and Animal Sciences University, Ludhiana, India

Dr. Rupika S. Rajakaruna, University of Peradeniya, Peradeniya, Sri Lanka

Dr. Bahar Baviskar, Wild-CER, Nagpur, Maharashtra 440013, India

Reviewers 2018-2020

Due to pausity of space, the list of reviewers for $2018-2020$ is available online.

The opinions expressed by the authors do not reflect the views of the Journal of Threatened Taxa, Wildlife Information Liaison Development Society, Zoo Outreach Organization, or any of the partners. The journal, the publisher, the host, and the partners are not responsible for the accuracy of the political boundaries shown in the maps by the authors.

Journal of Threatened Taxa is indexed/abstracted in Bibliography of Systematic Mycology, Biological Abstracts, BIOSIS Previews, CAB Abstracts, EBSCO, Google Scholar, Index Copernicus, Index Fungorum, JournalSeek, National Academy of Agricultural Sciences, NewJour, OCLC WorldCat, SCOPUS, Stanford University Libraries, Virtual Library of Biology, Zoological Records.

NAAS rating (India) 5.64
Print copies of the Journal are available at cost. Write to:

The Managing Editor, JoTT,

c/o Wildlife Information Liaison Development Society,

No. 12, Thiruvannamalai Nagar, Saravanampatti - Kalapatti Road,

Saravanampatti, Coimbatore, Tamil Nadu 641035, India

ravi@threatenedtaxa.org 


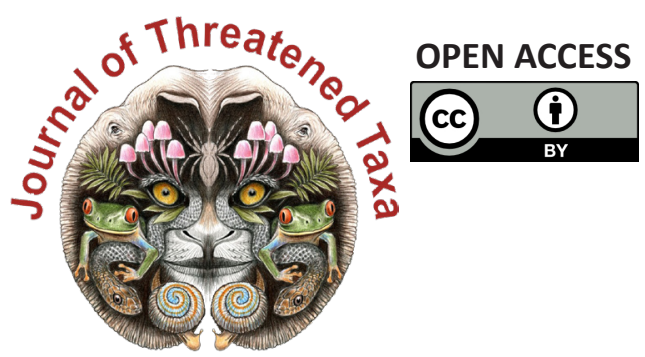

www.threatenedtaxa.org

The Journal of Threatened Taxa (JoTT) is dedicated to building evidence for conservation globally by publishing peer-reviewed articles online every month at a reasonably rapid rate at www.threatenedtaxa.org. All articles published in JoTT are registered under Creative Commons Attribution 4.0 International License unless otherwise mentioned. JoTT allows allows unrestricted use, reproduction, and distribution of articles in any medium by providing adequate credit to the author(s) and the source of publication.

ISSN 0974-7907 (Online) I ISSN $0974-7893$ (Print)

\section{November 2021 | Vol. 13 | No. 13 | Pages: 19887-20142 \\ Date of Publication: 26 November 2021 (Online \& Print) DOI: 10.11609/jott.2021.13.13.19887-20142}

\section{Article}

An inventory of geometrid moths (Lepidoptera: Geometroidea: Geometridae) of KalakadMundanthurai Tiger Reserve, India

- Geetha Iyer, Dieter Stüning \& Sanjay Sondhi, Pp. 19887-19920

\section{Communications}

Roadkills of Lowland Tapir Tapirus terrestris (Mammalia: Perissodactyla: Tapiridae) in one of its last refuges in the Atlantic Forest

- Aureo Banhos, Andressa Gatti, Marcelo Renan de Deus Santos, Leonardo Merçon,

Ilka Westermeyer, Natália Carneiro Ardente, Luis Francisco Oliveira Pereira Gonzaga, Lucas Mendes Barreto, Lucas Damásio, Tomas Lima Rocha, Vitor Roberto Schettino, Renata Valls, Helena Godoy Bergallo, Marcos Vinicius Freitas Silva, Athelson Stefanon Bittencourt, Danielle de Oliveira Moreira \& Ana Carolina Srbek-Araujo, Pp. 19921-19929

Scientific contributions and learning experiences of citizen volunteers with a small cat project in Sanjay Gandhi National Park, Mumbai, India

- Shomita Mukherjee, R. Nandini, P.V. Karunakaran \& Nayan Khanolkar, Pp. 19930-19936

Seasonal food preferences and group activity pattern of Blackbuck Antilope cervicapra (L., 1758) (Mammalia: Cetartiodactyla: Bovidae) in a semi-arid region of western Haryana, India

- Vikram Delu, Dharambir Singh, Sumit Dookia, Priya \& Kiran, Pp. 19937-19947

Studies on the habitats of Grey Francolin Francolinus pondicerianus (J.F. Gmelin, 1789) (Galliformes: Phasianidae) in northern districts of Tamil Nadu, India

- M. Pandian, Pp. 19948-19955

Recovery of vulture population in roosting and scavenging areas of Bastar and Bijapur, Chhattisgarh, India

- Sushil Kumar Dutta, Muntaz Khan, P.R.S. Nagi, Santosh Durgam \& Surabhi Dutta, Pp. 19956-19963

A geographical assessment of Chariganga and Arpara Beel (wetlands) of Nadia, West Bengal as a habitat of wetland birds

- Mehedi Hasan Mandal, Arindam Roy \& Giyasuddin Siddique, Pp. 19964-19975

Phenotypic plasticity in Barilius vagra (Hamilton, 1822) (Teleostei: Danionidae) from two geographically distinct river basins of Indian Himalaya

- Sumit Kumar, Sharali Sharma \& Deepak Singh, Pp. 19976-19984

Taxonomic notes, a new species, and a key to Indian species of the click beetle genus Cryptalaus Ôhira, 1967 (Coleoptera: Elateridae: Agrypninae)

- Harshad Parekar \& Amol Patwardhan, Pp. 19985-19999

Niche overlap of benthic macrofauna in a tropical estuary: diurnal variation

- Mário Herculano de Oliveira, Lidiane Gomes de Lima, Caroline Stefani da Silva Lima, Jéssica de Oliveira Lima Gomes, Franciely Ferreira Paiva, Graciele de Barros, Carlinda Railly Medeiros \& Joseline Molozzi, Pp. 20000-20010

Diversity of aquatic insects and biomonitoring of water quality in the upper Ganga River, a Ramsar site: a preliminary assessment

- Kritish De, Arkojyoti Sarkar, Kritika Singh, Virendra Prasad Uniyal, Jeyaraj Antony Johnson \& Syed Ainul Hussain, Pp. 20011-20018

Patterns of forest cover loss in the terrestrial Key Biodiversity Areas in the Philippines: critical habitat conservation priorities

- Bernard Peter O. Daipan, Pp. 20019-20032

The woody flora of Shettihalli Wildlife Sanctuary, central Western Ghats of Karnataka, India - A checklist

- Kanda Naveen Babu, Kurian Ayushi, Vincy K. Wilson, Narayanan Ayyappan \&

Narayanaswamy Parthasarathy, Pp. 20033-20055

Reproductive biology of Ophiorrhiza caudata C.E.C.Fisch. (Rubiaceae), an endemic and endangered creeping perennial herb of the Western Ghats, India

- Maria Theresa, Appukuttan Kamalabai Sreekala \& Jayalakshmi Mohanlal, Pp. 20056-20065
Short Communications

Successful rescue, medical management, rehabilitation, and translocation of a Red Panda Ailurus fulgens (Mammalia: Carnivora: Ailuridae) in Arunachal Pradesh, India - Jahan Ahmed, Sorang Tadap, Millo Tasser, Koj Rinya, Nekibuddin Ahmed \& Sunil Kyarong, Pp. 20066-20071

A rare photographic record of Eurasian Otter Lutra lutra with a note on its habitat from the Bhagirathi Basin, western Himalaya, India

- Ranjana Pal, Aashna Sharma, Vineet Kumar Dubey, Tapajit Bhattacharya, Jeyaraj Antony Johnson, Kuppusamy Sivakumar \& Sambandam Sathyakumar, Pp. 20072-20077

The first record of Medog Gliding Frog Rhacophorus translineatus Wu, 1977 (Anura: Rhacophoridae) from Chhukha District, Bhutan

- Sonam Lhendup \& Bal Krishna Koirala, Pp. 20078-20083

First record of a freshwater crab, Maydelliathelphusa masoniana (Henderson, 1893) (Decapoda: Brachyura: Gecarcinucidae) from West Bengal, India

- Ram Krishna Das, Pp. 20084-20089

Butterflies of Amrabad Tiger Reserve, Telangana, India

- Deepa Jaiswal, B. Bharath, M. Karuthapandi, Shrikant Jadhav, S. Prabakaran \& S. Rehanuma Sulthana, Pp. 20090-20097

An enumeration of the flowering plants of Kyongnosla Alpine Sanctuary in eastern Sikkim, India

- Sudhansu Sekhar Dash, Subhajit Lahiri \& Ashiho Asoshii Mao, Pp. 20098-20117

A new record of psychrotrophic Paecilomyces formosus (Eurotiales: Ascomycota) from India: morphological and molecular characterization

- Skarma Nonzom \& Geeta Sumbali, Pp. 20118-20123

Notes

Study on incidence and pathology of gastrointestinal parasitic infections in Nilgai Boselaphus tragocamelus in Hisar, Haryana, India

- Maneesh Sharma, B.L. Jangir, D. Lather, G.A. Chandratre, V. Nehra, K.K. Jakhar \& G. Narang, Pp. 20124-20127

An unusual vocalization of Brown Hawk-Owl Ninox scutulata (Raffles, 1822) (Aves:

Strigiformes: Strigidae) recorded from Kerala, India

- Riju P. Nair \& Shine Raj Tholkudiyil, Pp. 20128-20129

New distribution data on the genus Maripanthus Maddison, 2020 (Araneae: Salticidae) from southern India

- A. Asima, John T.D. Caleb, Dhruv A. Prajapati \& G. Prasad, Pp. 20130-20132

On the IUCN status of Boesenbergia albolutea and B. rubrolutea (Zingiberaceae) and typification of $B$. rubrolutea

- K. Aishwarya \& M. Sabu, Pp. 20133-20135

New records of mass seeding Cephalostachyum latifolium Munro (Poaceae) along the midelevation broadleaved forest of Sarpang district, Bhutan

- Jigme Tenzin, Sangay Nidup \& Dago Dorji, Pp. 20136-20139

Response

If habitat heterogeneity is effective for conservation of butterflies in urban landscapes of Delhi, India?' Unethical publication based on data manipulation

- Sanjay Keshari Das \& Rita Singh, Pp. 20140-20142

Publisher \& Host
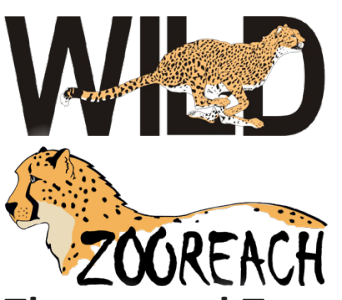

Threatened Taxa 